\title{
Research on the Risk and Countermeasure of China's Foreign Direct Investment under the Background of the Belt and Road Initiative
}

\author{
Zhou Siyu ${ }^{1, a, *}$, Liu Tianshan ${ }^{2, b}$ \\ ${ }^{1}$ Beijing Jiaotong University, Haidian District, Beijing, China \\ ${ }^{2}$ Beijing Jiaotong University , Haidian District, Beijing, China \\ a2471301666@qq.com, bltiansh@126.com \\ Zhou Siyu
}

Keywords: The Belt and Road Initiative; FDI; Risk assessment; CROIC-IWEP

\begin{abstract}
Chinese enterprises overseas investment is facing a series of direct investment risk, under the Background of The Belt and Road Initiative. Based on the current situation and characteristics of China's direct investment in the Belt and Road economic zone, this paper analyzes the investment data of Chinese enterprises. Then this paper evaluates the country's investment risk based on the analysis results. Finally, on the basis of the evaluation results, this paper puts forward the risk avoidance measures from the view of government and enterprises respectively. This paper argues that the government should further deepen the cooperation mechanism with the countries along the Belt and Road, strengthen the construction of foreign investment guarantee mechanism and improve the pertinence of the "going out" policy; Enterprises should improve the risk assessment mechanism and make full use of the social resources of the host country. Investment mechanism innovation and territorial management need to be carried out.
\end{abstract}

\section{Introduction}

In March 2015, Chinese government released "Vision and Action to Promote the Silk Road Economic Belt and the 21st Century Maritime Silk Road" which marking The Belt and Road Initiative ran into the overall promotion phase. The Belt and Road Initiative Influences Asia, Europe and Africa, involving more than 40 billion people. Under this background, China's direct investment in the Belt and Road economic zone grows rapidly. The Belt and Road Initiative is of great significance to the economic development of the world economic integration. It can promote the political, economic and cultural exchanges between china and involved countries. But at the same time, China is also faced with investment risk and security problems from these countries and regions. It is important to strengthen the risk analysis of the host countries along the Belt and Road.

There are many researches about the Belt and Road Initiative. Xia Xianliang proposed the Belt and Road Initiative would change the current world economic order. Peyrouse studied the economic relationship between China and Africa. Liang Dunshi analyzed the opportunities brought by the strategy to the coal industry. Manoharan explored a mutually beneficial model of cooperation between China and Sri Lanka. The study of national risks came from international banking cross-border business in the 20th century. At present there are three rating standards, namely, Euro Money' s Country Risk Index, ICRG and CROIC. This paper use the data from ICRG and CROIC.

\section{Analysis of the Status of China 's Investment in the Belt and Road economic zone.}

With the development of the Belt and Road initiative, the relation between China and countries in this zone becomes more closely. China's FDI in this zone kept a steady growth from 2004 to 2014. The investment industry covers a wide range of industries .In 2004, China's direct investment stocks in this zone were only $\$ 1,333$ million, and in 2014 the figure reached $\$ 92.46$ billion.

Overall, China has a wide range of direct investment areas in the Belt and Road zone, but there are great differences between the different regions. As for investment flow, China and Southeast 
Asia's economic and trade relations are the most closely.Fig.1shows the location distribution of China's direct investment in the Belt and Road zone in 2014. It is the Southeast Asian region that attracts most of China's direct investment. The total investment amounted to 47,648.31 million US dollars, accounting for 52 percent of the total stock. China's direct investment in Southeast Asia is mainly concentrated in Singapore and Malaysia, while investment in the rest of the country is more balanced. As for investment stock, China's direct investment in Russia-Mongolia region in 2014 amounted to 1245.709 million US dollars.

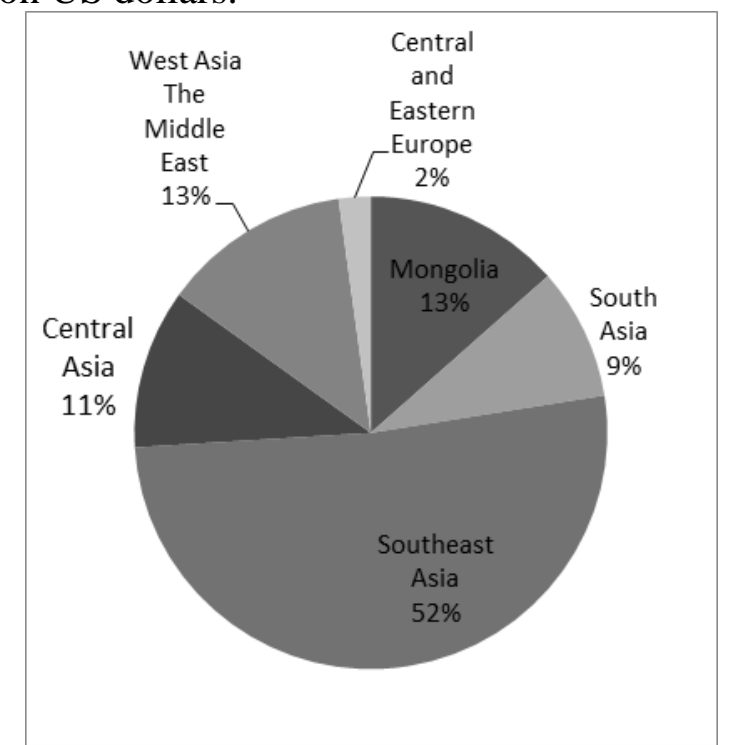

Fig.1. China's FDI stock in the Belt and Road zone in 2014

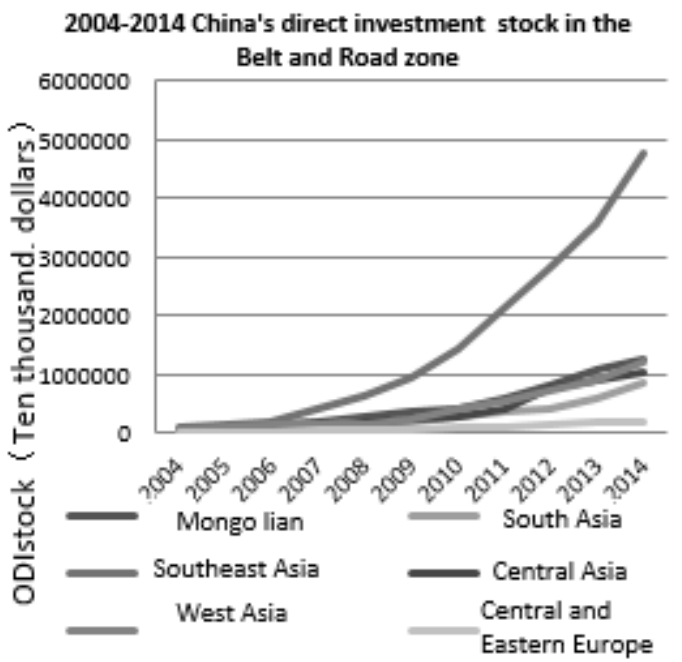

Fig.2. China's FDI stock in the Belt and Road zone

Fig.2.describes the trend of changes in China's foreign direct investment (FDI) in the Belt and Road zone. As is shown in figure 2-3, China's foreign direct investment stocks in the Belt and Road zone has an overall growth trend, while the growth rates are different in different regions. The figure shows that investment in Southeast Asia grew fastest. And the growth of investment in the Middle East and Russia-based regions was relatively stable.

\section{Analysis of China's Foreign Investment Risk in the Belt and Road zone}

The Belt and Road Initiative brought China more opportunities, but also brought various risks . China's direct investment is mainly concentrated in Southeast Asia and Russia-Mongolia region while South Asia and Central and Eastern Europe attract less direct investment. China's direct investment is mainly concentrated in some development countries, which lack of foreign exchange reserves. It is likely to suffer the impact of international financial markets. The unstable financial environment of the host country poses a severe challenge to China's FDI. Because China's FDI is 
concentrated in countries with social unrest, the risks posed by political fluctuations cannot be ignored.

3.1 Analysis of Overall Risk Distribution. According to the ICRG 2014 data, 50 countries are calculated for risk according to their formula. The comprehensive risk score is 100 points. The higher the score means the lower risk. Major national risk distribution is characterized by normal distribution. The overall risk is acceptable while there are a few countries with high risk. Countries with lower risk are mainly in Asia and Europe. And the overall risk in South Asia is higher.

3.2 Economic Risk Analysis of Host Countries. This paper choose 16 countries which attract most of China's FDI. Then this paper calculates the economic and non-economic risks of 16 countries according to the basic data of CROIC-IWEP.

Table1.Economic risks ranking in major countries

\begin{tabular}{c|c|c}
\hline \hline country & $\begin{array}{c}\text { economic base } \\
\text { ranking }\end{array}$ & Solvency ranking \\
\hline Singapore & 1 & 8 \\
\hline Kazakhstan & 3 & 10 \\
\hline Russia & 4 & 4 \\
\hline Indonesia & 9 & 3 \\
\hline Germany & 2 & 1 \\
\hline Myanmar & 11 & 13 \\
\hline Mongolia & 12 & 14 \\
\hline Cambodia & 15 & 12 \\
\hline Iran & 13 & 2 \\
\hline Laos & 16 & 16 \\
\hline Thailand & 8 & 7 \\
\hline India & 5 & 11 \\
\hline Pakistan & 10 & 9 \\
\hline Vietnam & 14 & 6 \\
\hline Malaysia & 7 & 5 \\
\hline Philippines & 6 &
\end{tabular}

Table2. Non-economic risks ranking in

\begin{tabular}{|c|c|c|c|c|}
\hline \multirow[b]{2}{*}{ country } & \multirow{2}{*}{$\begin{array}{l}\text { non - } \\
\text { econo } \\
\text { mic } \\
\text { risk } \\
\text { index }\end{array}$} & \multicolumn{2}{|c|}{$\begin{array}{l}\text { Seccondary } \\
\text { indicators }\end{array}$} & \multirow[b]{2}{*}{$\begin{array}{l}\text { Relatl } \\
\text { Ons } \\
\text { with } \\
\text { China }\end{array}$} \\
\hline & & $\begin{array}{l}\text { Social } \\
\text { flexibi } \\
\text { lity }\end{array}$ & $\begin{array}{l}\text { Politic } \\
\text { al risk }\end{array}$ & \\
\hline Singa & 7.05 & 7.24 & 7.83 & 5.27 \\
\hline Kazakh & 5.20 & 5.45 & 4.37 & 6.61 \\
\hline Russia & 4.27 & 5.26 & 3.45 & 4.89 \\
\hline Indones & 3.83 & 4.51 & 2.88 & 5.03 \\
\hline German & 5.49 & 5.50 & 6.03 & 4.44 \\
\hline Myanm & 4.05 & 4.52 & 2.22 & 7.27 \\
\hline Mongol & 4.91 & 5.03 & 3.65 & 7.27 \\
\hline Cambo & 1.34 & 5.12 & -3.6 & 7.42 \\
\hline Iran & 4.11 & 4.36 & 2.69 & 6.67 \\
\hline Laos & 1.44 & 4.75 & -3.42 & 7.84 \\
\hline Thailan & 3.89 & 4.68 & 3.12 & 4.62 \\
\hline India & 3.77 & 4.95 & 3.23 & 3.69 \\
\hline Pakista & 4.01 & 3.72 & 2.30 & 7.68 \\
\hline Vietna & 4.44 & 4.39 & 4.19 & 4.99 \\
\hline Malaysi & 5.28 & 6.3 & 4.97 & 4.89 \\
\hline Philippi & 3.91 & 4.42 & 3.36 & 4.53 \\
\hline
\end{tabular}


First, we analyzed the major economic risks. Based on CROIC-IWEP, economic base and solvency are popular indicators used to describe the national economic risks. There are a number of subordinate indicators for descriptive comparison. So the economic risk is shown in the order of ranking. For example, $24.65 \%$ of China's investment in Singapore is facing lower capitalist economic risk, $42.86 \%$ capital is facing moderate economic risk, $18.17 \%$ is facing higher economic risk. But in Burma, Laos, and India China's investment is facing higher economic risks. Economic base and solvency in such countries are mostly below the average.

3.3 Non-economic Risk Analysis of Host Countries. Then, we analyzed the major non-economic risks. Non-economic risks can be further divided into social elasticity, political risk and relations with China. This paper first quantifies the raw data of CROIC-IWEP, so that the sub-indicators can be compared. Second this paper quantifies the weight of the weighted calculation of the secondary indicators, according to CROIC-IWEP formula. And then Non - economic risk index can be calculated by the secondary index. The non-economic risk of major countries is shown in Table2. According to the proportion of capital stock, China's investment non-economic risk can be divided into three levels. As is shown in Table II, $40.41 \%$ of the investment is facing low risk, $12.83 \%$ of the investment is facing moderate risk, $25.04 \%$ of the investment is facing high risk and $7.4 \%$ of the investment is facing high risk. Overall, China's capital is in the face of low-risk or medium-level risk in the major countries in the Belt and Road economic zone. Less than $20 \%$ of China's invest face higher economic risks while about $30 \%$ face higher non-economic risks, that is, non-economic risk is relatively large. So this paper argues that better relations with China can alleviate non-economic risks.

\section{Risk Avoidance Measures under the Background of The Belt and Road Initiative}

4.1 Strengthen Strategic Cooperation. In order to avoid the political risk of investment, the government should actively cooperate with the countries the Belt and Road zone. For example, the government could sign cooperation agreement with these countries. The cooperation agreement can provide more favorable conditions to convey mutually beneficial information. In addition, the government should strengthen the protection system construction and provide legal protection for the interests of foreign investment enterprises. We can make use of the international system to safeguard the legitimate interests of foreign investment enterprises and reduce their investment risk. Furthermore the government can establish an overseas investment information center to collect information and provide services for foreign enterprises.

4.2 Balance Investment Location Distribution. The level of development is higher and the infrastructure is better in Central and Eastern Europe. Increasing direct investment in Central and Eastern Europe and strengthening trade links with Central and Eastern Europe are in line with the interests of both sides. It is important to expand the scope of radiation and deepen its impact. At this stage, China should strengthen the transport and infrastructure construction that ties China with Central and Eastern Europe. Chinese government should promote the development of bilateral trade through the Eurasian Continental Bridge.

4.3 Balance Investment Structure Distribution. In view of the imbalance of China's foreign investment structure, the government needs to guide and encourage enterprises to optimize the investment structure on the one hand and on the other hand to strengthen cooperation with the host country. The government can provide institutional guarantee and support for Chinese enterprises to enter more industries through signing bilateral investment agreements and improving the overseas investment promotion policy system. In order to avoid financial risks, enterprises should actively carry out foreign investment innovation. It is necessary for the enterprises operated abroad to comply with local laws and regulations.

\section{References}

[1] Peyrouse and Raballand, The "China Story" and China' s International Image,Contemporary International Relations,pp.17-25,2015. 
[2] Liang Dunshi. The opportunity for the development of China's coal industry under the Background of the Belt and Road Initiative, Coal Economic Research, pp.10-15,2015.

[3] He Maochun. Research on the Riskof China's Foreign Direct Investment under the Background of the Belt and Road Initiative, Chinese circulation economy,pp.115-121,2015.

[4] Tian Ze. Research on the investment environment of China in the Middle East countries under the Background of the Belt and Road Initiative, Discussion on modern economy, pp.45-49, 2016.

[5] Manoharan. What determines Chinese outward FDI?, Journal of World Business,pp.29-37,2010. 